EESTI NSV TEADUSTE AKADEEMIA TOIMETISED. VII KÖIDE

BIOLOOGILINE SEERIA. 1958, NR. 4

ИЗВЕСТИЯ АКАДЕМИИ НАУК ЭСТОНСКОЙ ССР. ТОМ VII

СЕРИЯ БИОЛОГИЧЕСКАЯ, 1958, № 4

\title{
ТЮЛЬПАНЫ В ЭСТОНСКОЙ ССР
}

\section{В. Н. ЕСИНОВСКАЯ, \\ кандидат сельскохозяйственных наук}

\begin{abstract}
Разводимый в настоящее время в Эстонской ССР сортимент тюльпанов не удовлетворяет запросы населения в том отношении, что очень высокий процент поступающих в продажу цветов падает на поздние сорта, зацветающие в конце мая - начале июня, а также на сорта с кратковременным периодом цветения и незначительно размножаемые в условиях Эстонской ССР.
\end{abstract}

Ввиду этого необходимо приступить к разведению ранозацветающих сортов, более однородных по декоративным признакам и с более продолжительным периодом цветения, а также ароматных сортов, отличающихся интенсивностью размножения и иммуностью к заболеваниям. Кроме выведения культурных отечественных сортов и отбора сеянцев, необходимо привлечение лучшего сортового материала, имеющегося в других зарубежных странах, а также широкое использование диких Бидов тюльпанов и посев семян от свободного опыления. Следует отметить, что явление пестрения в условиях Эстонской ССР наблюдалось крайне редко, реже $1 \%$.

Коллекция тюльпанов Института экспериментальной биологии Академии наук Эстонской ССР состоит в настоящее время из 210 сортов культурных и 30 видов диких тюльпанов.

Посадка луковиц обычно производилась в сентябре месяце. Подготовка почвы состояла в следующем: вспашка на глубину $18-20$ см с внесением в почву перед посадкой луковиц навоза из расчета 60 т (или компоста 80 т), калийной соли 4 ц, суперфосфата 1 т, сернокислого аммония 3 ц и серы 80 кг на гектар. Двукратное боронование с выборкой сорняков и поделка гряд. Ширина гряд 1 м 20 см, высота $13-15$ см. Луковицы сажались в бороздки на глубину $7-8$ см. Расстояние при посадке $10 \times 20 \mathrm{~cm}$.

В течение вегетационного периода проводилась четырехкратная подкормка с прополкой и рыхлением. Сухие удобрения вносились в следующих количествах из расчета на 1 га: сернокислого аммония - 5 ц, суперфосфата -4 ц, калийной соли -2 ц. При первой подкормке добавлялся компостированный торф из расчета 35 т на га. При третьей жидкой подкормке разбавленной. водой навозной жижей $(1: 4)$ добавлялось еще очень незначительное количество минеральных удобрений. Полив разбавленной навозной жижей проводился из расчета 1 ведро (10 литров) на 1,5 м² почвы, а затем полив чистой водой.

Луковицы обычно выкапывались через два года, в конце июля.

Одним из важных качеств тюльпанов, кроме декоративных, является степень их размножения. Определялся истинный коэффициент размноже- 
ния - отношение числа выкопанных луковиц к числу выкопанных гнезд, - выражернный в процентах.* Кроме того, проведен анализ гнезд выкопанных сортов тюльпанов и учет луковиц различных разборов. Но необходимо отметить, что интенсивность размножения тюльпанов определяется выходом луковиц определенной величины и зрелости, дающих при посадке цветущие растения.

Ниже приведены кондиции, установленные Ленинградским цветочнопитомническим трестом для его хозяйств в 1951 году.*

\begin{tabular}{r|c|c|c|c}
\hline Разбор & I & II & III & IV \\
\hline Диаметр, см & 3 и более & $2-2,9$ & $1-1,9$ & менее 1
\end{tabular}

Луковицы I и II разборов обязательно дают цветущие растения. Луковицы III разбора не всегда дают цветущие растения.

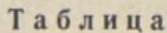

количества выкопанных луковиц различного разбора

(посадка проведена луковицами I и II разборов)

\begin{tabular}{|c|c|c|c|c|c|c|c|c|c|c|}
\hline \multirow{3}{*}{$\begin{array}{c}\text { Группа и назва- } \\
\text { ние сорта }\end{array}$} & \multirow{3}{*}{ 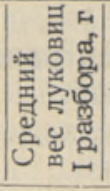 } & \multicolumn{8}{|c|}{ 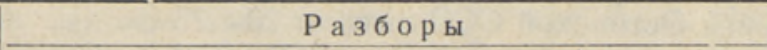 } & \multirow{3}{*}{ 吾 } \\
\hline & & \multicolumn{2}{|c|}{ I } & \multicolumn{2}{|c|}{ II } & \multicolumn{2}{|c|}{ III } & \multicolumn{2}{|c|}{ IV } & \\
\hline & & число & $\%$ & число & $\%$ & число & $\%$ & число & $\%$ & \\
\hline \multicolumn{11}{|l|}{ ДАРВИНОВСКИЕ } \\
\hline $\begin{array}{l}\text { Aviator Havaen } \\
\text { Gretchen } \\
\text { La Tulipe Noire } \\
\text { Rw. Ewbank } \\
\text { The Bishop } \\
\text { Victoire d'Olivière } \\
\text { William Copland } \\
\text { Yellow Giant }\end{array}$ & $\begin{array}{l}56 \\
43 \\
47 \\
37 \\
56 \\
\overline{37}\end{array}$ & $\begin{array}{l}5 \\
0 \\
6 \\
5 \\
1 \\
3 \\
0 \\
4\end{array}$ & $\begin{array}{r}11,9 \\
\overline{10,5} \\
6,5 \\
2,3 \\
5,6 \\
\overline{6,2}\end{array}$ & $\begin{array}{r}5 \\
11 \\
9 \\
9 \\
5 \\
13 \\
2 \\
3\end{array}$ & $\begin{array}{r}11,9 \\
11,1 \\
15,8 \\
11,7 \\
11,3 \\
24,0 \\
3,2 \\
4,6\end{array}$ & $\begin{array}{l}19 \\
35 \\
19 \\
37 \\
15 \\
23 \\
19 \\
19\end{array}$ & $\begin{array}{l}45,2 \\
35,4 \\
33,3 \\
48,0 \\
34,1 \\
42,6 \\
30,7 \\
29,2\end{array}$ & $\begin{array}{l}13 \\
53 \\
23 \\
26 \\
23 \\
15 \\
41 \\
39\end{array}$ & $\begin{array}{l}31,0 \\
53,5 \\
40,4 \\
33,8 \\
52,3 \\
27,8 \\
66,1 \\
60\end{array}$ & $\begin{array}{l}42 \\
99 \\
57 \\
77 \\
44 \\
54 \\
62 \\
65\end{array}$ \\
\hline \multicolumn{11}{|l|}{ ЛИЛЕИНЫЕ } \\
\hline $\begin{array}{l}\text { Picotée } \\
\text { Yellow Marvel }\end{array}$ & $\overline{44}$ & $\begin{array}{l}0 \\
3\end{array}$ & $\overline{2,4}$ & $\begin{array}{r}2 \\
17\end{array}$ & $\begin{array}{r}2,6 \\
13,7\end{array}$ & $\begin{array}{l}21 \\
18\end{array}$ & $\begin{array}{l}27,6 \\
14,5\end{array}$ & $\begin{array}{l}53 \\
86\end{array}$ & $\begin{array}{l}69,8 \\
69,4\end{array}$ & $\begin{array}{r}76 \\
124\end{array}$ \\
\hline $\begin{array}{l}\text { ПРОСТЫЕ } \\
\text { ПОЗДНИЕ } \\
\text { Belle Jeanne } \\
\text { Grenadier }\end{array}$ & $\frac{46}{-}$ & $\begin{array}{l}5 \\
0\end{array}$ & $\underline{6,7}$ & $\begin{array}{r}15 \\
5\end{array}$ & $\begin{array}{r}20,3 \\
8,9\end{array}$ & $\begin{array}{l}31 \\
10\end{array}$ & $\begin{array}{l}41,9 \\
17,9\end{array}$ & $\begin{array}{l}23 \\
41\end{array}$ & $\begin{array}{l}31,1 \\
73,2\end{array}$ & $\begin{array}{l}74 \\
56\end{array}$ \\
\hline \multicolumn{11}{|l|}{ ТРИУМФ } \\
\hline $\begin{array}{l}\text { Edith Eddy } \\
\text { Korneloros }\end{array}$ & $\begin{array}{l}40 \\
42\end{array}$ & $\begin{array}{l}5 \\
5\end{array}$ & $\begin{array}{l}10,6 \\
12,2\end{array}$ & $\begin{array}{r}13 \\
2\end{array}$ & $\begin{array}{r}27,7 \\
4,9\end{array}$ & $\begin{array}{r}8 \\
14\end{array}$ & $\begin{array}{l}17,0 \\
34,1\end{array}$ & $\begin{array}{l}21 \\
20\end{array}$ & $\begin{array}{l}44,7 \\
48,8\end{array}$ & $\begin{array}{l}47 \\
41\end{array}$ \\
\hline \multicolumn{11}{|l|}{ ПОПУГАЙНЫЕ } \\
\hline Perfecta & 43 & 2 & 5,4 & 6 & 16,2 & 11 & 29,7 & 18 & 48,7 & 37 \\
\hline
\end{tabular}

Как видно из таблицы, наибольшее количество луковиц I разбора $(12,2 \%)$ у сорта Korneforos, а II разбора $(27,7 \%)$ - у сорта Edith Eddy.

* Силин а 3. М., Культура тюльпанов в Ленинградской области. Интродукция растений и зеленое строительство. Тр. Ботанич. ин-та им. В. Л. Комарова АН СCCP, серия VI, вып. 3, 1953. 
Увеличения интенсивности размножения можно добиться путем совершенствования агротехники. Желательно применение одной-двух подкормоқ органическими удобрениями в течение вегетационного периода, отбор интенсивно размножающихся сортов, создание своих местных гибридных сортов, а также проведение своевременных прополок и рыхлений.

Ниже приведено описание лучших сортов тюльпанов, выращенных в Эстонской ССР. Описание сортов приводится по группам, принятым для тюльпанов. Группы расположены по срокам зацветания. Описываемые сорта тюльпанов не повреждались в ЭССР ни луковичным клещиком, ни серой гнилью.

\section{Простые ранние тюльпаны}

Сорта данной группы являются наиболее ранозацветающими тюльпанами, а также пригодны для ранней выгонки. В условиях Эстонской ССР они обычно зацветают $14-19 \mathrm{~V}$, а в более холодные годы $23-25 \mathrm{~V}$. Средняя высота тюльпанов группы простых ранних составляет в Эстонии 40-50 см. В коллекции имеются тюльпаны со средней высотой 50-65 см. Сорта: Prince of Austria, Sunburst, Thomas Edison, Weisser Schwan и другие. Сорта Orchid Blue и Vermillon Brillant достигают в условиях Әстонской ССР высоты 70-75 см.

Одним из преимуществ данной группы является раннее цветение, что очень ценно в условиях Севера, а также пригодность их для ранней выгонки зимою и для оформления бордюров. При срезке многие сорта отличаются продолжительностью цветения в воде.

\section{La Reine maxima (Великая королева)}

Цветы среднего размера, длиной до 7 см, бокаловидной формы. Цветок белый с слегка кремовым оттенком в центре листочков околоцветника с наружной и внутренней сторон. Основание листочков околоцветника внутри желтое. Вершина у наружных листочков околоцветника округлая, а у внутренних с очень незначительной маленькой выемкой. Тычиночные нити желтого цвета, средней длины, незначительно короче пестика. Пыльники зеленоватые с желтоватым оттенком, почти одной длины с тычиночными нитями. Аромат нежный, приятный. Растение среднего размера до 40-45 см высоты. Начало цветения $-14-25 \mathrm{~V}$, а холодной весной 1955 г. - 2 VI. Длительность цветения сорта $12-22$ дня, при срезке - 8-9 дней. Сорт хорошо размножается. Истинный коэффициент размножения был $500-600 \%$ * В посадках тюльпанов Эстонской ССР встречается крайне редко.

\section{Prince of Austria (Принц австрийский)}

Цветы крупные, длиной до 8 см, яйцевидной формы. Окраска красная с красновато-шарлаховым оттенком по краям листочков околоцветника. Снаружи в центре листочков околоцветника наблюдается более темный оттенок с незначительным сизым налетом. Продольные бороздки рельефно выражены. На вершине внутренних листочков околоцветника незначительная выемка. Дно широкое, желтое с незначительными синеватыми щтрихами, просвечивающее у основания листочков околоцветника. Тычиночные нити желтые, среднего размера, пыльники фиолетовые. Аромат незначительный. Средняя высота растений 55-65 см. Начало цветения $19-24 \mathrm{~V}$, а в холодный 1955 г. $-6 \mathrm{VI}$. Длительность цветения сорта

* Истинный коэффициент размножения как здесь, так и ниже приводится за 2 года. 
10-29 дней, при срезке - 8-10 дней. Истинный коэффициент размножения - 500-600\%. Сорт заслуживает внимания, как один из самых красивых Простых ранних тюльпанов. В Әстонской ССР встречается редко.

\section{Weisser Schwan (Белый лебедь)}

Цветы крупные, длиной до 9,1 см, бокаловидной формы. Листочки околоцветника белые, а снаружи в центре незначительно кремового оттенка. Вершина наружных листочков околоцветника острая, а внутренних округлая. Края незначительно зазубрены. В центральной части листочков околоцветника с внутренней стороны рельефно выражены продольные бороздки. Основание у внутренних листочков околоцветника светло-желтое. Тычинки короче пестика. Нити белые, среднего размера. Пыльники короткие, желтые. У цветочного стебля имеется красивый изгиб, напоминающий изгиб шеи лебедя. Аромат приятный, сильный, чувствуется на расстоянии. При полном цветении хорошо сохраняет форму цветка. Высота растения 50-60 см. В течение пяти лет зацветал одним из первых. Начало цветения 14-19 V, а в 1955 г., ввиду поздней холодной весны, $30 \mathrm{~V}$. Длительность цветения $17-36$ дней, при срезке - 10-11 дней. Данный сорт по красоте цветов, ароматичности, раннему зацветанию, продолжительности цветения в открытом грунте и при срезке и хорошему размножению занимает одно из первых мест среди тюльпанов. Истинный коэффициент размножения - $550-650 \%$. Среди тюльпанов Эстонской ССР встречается изредка.

Широко распространенная группа ранних сортов Duc van Tholl, как показывают многолетние наблюдения, обычно зацветает в условиях Эстонской ССР позднее Простых ранних тюльпанов. Простые ранние тюльпаны зацветали 14-19 V, a Duc van Tholl $-22-30 \mathrm{~V}$.

\section{Двойные , ранние тюльпаны}

Тюльпаны этой группы характеризуются наличием махровости, ранним цветением и низкорослостью. Средняя высота растений в условиях Эстонской ССР 35-45 см, за исключением одного высокого сорта Rubra Maxima, средняя высота которого - 50-60 см. Данная группа сортов, кроме культуры в открытом грунте при оформлении парков и скверов, пригодна и для ранней выгонки. В условиях Эстонской ССР тюльпаны данной группы обычно зацветают на $1-2$ дня позднее группы Простых ранних тюльпанов $(15-20 \mathrm{~V})$, а в более холодные годы $25-27 \mathrm{~V}$.

\section{Murillo (Мурильо)}

Данный сорт благодаря своим спортивным отклонениям дал много сортов Двойных ранних тюльпанов. Цветы махровые, красивые, чашевидной формы, среднего размера, до 7 см длины, белого цвета. С наружной стороны листочков околоцветника чуть заметный розоватый оттенок, края сильно изрезаны. Основание с внутренней стороны желтого цвета. Количество листочков околоцветника в среднем 18-19 штук, но бывает больше. Тычинок - 8-9, короче пестика. Тычиночные нити желтые, короткие. Пылинки желтые, короче нитей. Рыльце пестика четырехлопастное. Аромат нежный, приятный. Средняя высота растений 35-45 см. В группе Двойных ранних тюльпанов цветет одним из первых. Начало цветения $15-22 \mathrm{~V}$, в холодную и позднюю весну 1955 г. -3 VI. Длительность цветения $14-23$ дня, при срезке - 7-8 дней. Сорт хорошо размножается. Истинный коэффициент размножения $700-800 \%$. Является 
одним из красивейших сортов Двойных ранних тюльпанов. В Эстонской ССР встречается редко.

\section{Rubra maxima (Красный крупный)}

Цветы среднего размера, до 7 см длины, темно-красные, двойные, чашевидной формы. Снаружи цветы имеют незначительный коричневатый оттенок. Верхняя часть листочков околоцветника с незначительным сизым оттенком. Основание листочков околоцветника - желтое. У центральных листочков околоцветника с внутренней стороны в верхней части основания желтый оттенок переходит в оливковый. Края листочков околоцветника у внутреннего круга сильно зазубрены. Количество листочков околоцветника в среднем 20-22 штуки. Тычинок-6-8. Тычиночные нити короткие, желтые. Пыльники желтые, длиннее тычиночных нитей. Рыльце пестика преимущественно четырехлопастное. Аромат сильный, приятный. Сорт является относительно высоким среди прочих Двойных ранних тюльпанов: средняя высота его - 50-60 см, в то время как у прочих сортов данной группы она равна $35-40$ см. Начало цветения $26-29 \mathrm{~V}$, а в холодный 1955 г. - 1 VI. Длительность цветения сорта 14-20 дней, при срезке - 8-9 дней. Хорошо размножается в условиях Эстонской ССР. Истинный коэффициент размножения - 750 $800 \%$. Благодаря красоте своих цветов и высоте растения, Rubra maxima является одним из наиболее эффектных сортов группы Двойных ранних тюльпанов. Пригоден не только для оформления и выгонки, но и для срезки. Данный сорт очень широко распространен и является одним из основных сортов, культивируемых в Эстонской ССР.

\section{Teerose (Чайная роза)}

Цветы махровые, красивые, чашевидной формы, среднего размера, до 7 см длины. Окраска желтая. В верхней части наружных листочков околоцветника имеются розовые штрихи, которые придают наружной стороне цветка оттенок чайной розы. В центре листочков цветка продольные просвечивающие бороздки. Основание листочков околоцветника желтое. Вершина и края зазубрены.

Среднее количество листочков околоцветника 16-20 штук. Тычинок 8-9. Тычиночные нити короткие, светло-серые. Пыльники желтые, длиннее нитей. Рыльце пестика четырехлопастное. Аромат нежный, приятный. Средняя высота растений 35-45 см. Цветет одним из первых из сортов группы Двойных ранних тюльпанов. Начало цветения $15-28 \mathrm{~V}$, в холодную и позднюю весну 1955 г. - 2 VI. Продолжительность цветения сорта в открытом грунте - 15-36 дней, а при срезке - 8-11 дней. Истинный коэффициент размножения 350-400\%. Сорт Теerose благодаря своим красивого оттенка цветам, ароматичности и раннему цветению является одним из лучших сортов данной группы. Среди посадок тюльпанов Эстонской ССР встречается изредка.

\section{Менделевские тюльпаны}

Тюльпаны данной группы получены от скрещивания Простых ранних с Дарвиновскими. Сорта отличаются яркой окраской цветов и высотой стеблей. Тюльпаны Менделевской группы выше Простых ранних тюльпанов. Высота растений 47-57 см. В условиях Эстонской ССР начало цветения обычно $17-24 \mathrm{~V}$, а в холодные годы с поздней весной $-25-28 \mathrm{~V}$, т. е. всего на 2-3 дня позднее начала цветения Простых и Двойных ранних сортов. 
Менделевские тюльпаны используются для срезки, оформления и выгонки. Лучшим и наиболее красивым тюльпаном, зацветающим первым в течение ряда лет и имеющим замечательный аромат, является сорт Zenober.

\section{Zenober (Зенобер)}

Цветы бокаловидной формы, крупного размера, длиной до 8,1 см, ярко-красной окраски, очень эффектные и по своей форме выделяющиеся среди цветов других тюльпанов.

Вершина листочков околоцветника округлая с незначительной выемкой в центре, а вершина листочков околоцветника внешнего круга незначительно отогнута наружу, что создает сходство с цветами мака. На внутренней и внешней сторонах листочков околоцветника рельефно выделяются продольные бороздки. Основание с внутренней стороны на внутренних листочках околоцветника оливкового оттенка, а на наружных - фиолетово-оливкового оттенка. С наружной стороны у основания белый оттенок. Тычинки короче пестика. Нити тычинок фиолетовые с белым оттенком у основания, значительно длиннее фиолетово-оливковых пыльников. Аромат сильный, очень приятный, чувствуется на расстоянии. При полном расцветании хорошо сохраняет форму цветка. Средняя высота растений 50-60 см. Цветет одним из первых тюльпанов данной группы в течение ряда лет. Начало цветения сорта $17-22 \mathrm{~V}$, а в холодный 1955 г. 4 VI. Продолжительность цветения в открытом грунте $17-30$ дней, а при срезке - 8-10 дней. Истинный коэффициент размножения $750-800 \%$.

Благодаря своей выделяющейся красоте, изяществу цветов, ароматичности, раннему зацветанию и интенсивности размножения, является одним из лучших сортов коллекции.

Сорт Zenober среди тюльпанов Әстонской ССР встречается довольно редко.

Сортом, похожим на Zenober, является сорт Ant. Thoolen, тоже Менделевской группы, который отличается от сорта Zenober только желтой узкой полоской, окаймляющей основание. Остальные морфологические и физиологические признаки у обоих данных сортов совпадают.

\section{Дарвиновские тюльпаны}

Дарвиновские тюльпаны отличаются мощностью развития, высотой и наличием бокаловидных цветов различной окраски. Тюльпаны данной группы являются одними из самых высоких. Средняя высота растений в Эстонской ССР $56-66$ см, а у некоторых тюльпанов, например Aviator Havaen, Blue Aimable и др., доходит до 80 см. Тюльпаны этой группы обычно зацветают несколько позднее Менделевских тюльпанов $(27-31 \mathrm{~V})$. Пригодны для срезки, оформления, а некоторые сорта для выгонки.

\section{Kathleen Parlow (Кэтлин Парлоу)}

Цветы крупные, до 8,5 см длины, узкобокаловидной формы, красивой серебристо-розовой окраски, с более светлыми краями листочков околоцветника. В центре листочков околоцветника наблюдаются продольные беловатые бороздки. Вершина наружных листочков околоцветника округлая, а у листочков околоцветника внутреннего круга имеется незначительная выемка. Дно белое с незначительным фиолетово-синим окаймлением. Тычнночные нити небольшие, белые. Пыльники фиолетовые. Аромат нежный. При цветении очень хорошо сохраняет форму цветка. Некоторые растения до 70 см высоты. Начало цветения 4-6 VI, а в холодный

5 ENSV TA Toimetised B-4 58 
1955 г. - 16 VI. Длительность цветения сорта в открытом грунте 19-23 дня, а при срезке - 8-9 дней. Сорт Kathleen Parlow не встречается среди тюльпанов Эстонской ССР. Благодаря красивой окраске, изяществу цветов и продолжительности цветения, заслуживает внимания и распространения в Эстонской ССР.

\section{King Harold (Король Гарольд)}

Цветы крупные, длиной до 8 см, яйцевидной формы, темно-красного цвета с сизым налетом. Основание листочков околоцветника темно-фиолетовое, почти черное, окружено розово-сиреневой бороздкой, более светлой к краям листочков. С внешней стороны основание белого оттенка, переходящего в светло-сиреневый. Вершина листочков округлая с незначительно выдающимся острием в центре. Снаружи цветка видны рельефно выступающие продольные бороздки. Тычинки короче пестика. Нити тычинок и пыльники длинные, фиолетовые. Тычинки с сиреневым оттенком на вершине. Аромат приятный, нежный. При полном цветении хорошо сохраняет красивую форму цветка. Высота растений $60-70$ см.' Началю цветения $28 \mathrm{~V}-3 \mathrm{VI}$, а в холодный 1955 г. - 9 VI. Длительность цветения сорта 10-24 дня, при срезке - 8-12 дней. Истинный коэффициент размножения 1000-1060\%. Среди тюльпанов Эстонской ССР встречается изредка.

\section{La Tulipe Noire (Черный тюльпан)}

Давно известный старый сорт. Цветы бокаловидной формы, длиной до 5 см, черно-каштанового цвета с чуть заметным снаружи сизым налетом и рельефно выраженными продольными бороздками. Основание листочков околоцветника более темного оттенка. Тычиночные нити темносиние, а у основания белые. Пылинки темно-фиолетовые. Аромат незначительный. При полном расцветании очень хорошо сохраняет форму цветка, слабо раскрывая венчик. Высота растений 50-60 см. Начало цветения 27-30 V, а в холодный 1955 г. - 4 VI. Длительность цветения сорта в открытом грунте $11-25$ дней. Отличается наибольшей продолжительностью цветения при срезке - 9-14 дней, тогда как обычно цветы большинства сортов сохраняются при срезке, не теряя своих декоративных качеств, $7-8$ дней. Сорт хорошо размножается в Эстонской ССР. Истинный коэффициент размножения 550-600\%. La Tulipe Noire весьма распространен среди тюльпанов ЭССР. Благодаря красивому, почти черному оттенку цветов и высоте, является одним из наиболее красивых Дарвиновских сортов. Сорта Queen of the Night и The Sulton похожи на La Tulipe Noire, но с более красивыми цветами и более крупных размеров.

\section{Victoire d'Olivière (Виктуар д’Оливиер)}

Цветы крупные, до 8,5 см длины, бокаловидной формы, темно-карминового цвета с болеё темным оттенком с внутренней стороны и продольными бороздками с незначительным фиолетовым оттенком. Основание листочков околоцветника сиренево-фиолетовое, окаймленное розоватой бороздкой, переходящей в светло-сиреневую. Тычиночные нити и пыльники крупного размера, фиолетовой окраски. При цветении обычно имеет наклонное положение стеблей. Растения очень высокие - 65-80 см. Начало цветения $29 \mathrm{~V}-4 \mathrm{VI}$, а в холодный 1955 г. - 11 VI. Длительность цветения в открытом грунте $13-21$ день, при срезке - 8-10 дней. Истинный коэффициент размножения 1000-1100\%. Благодаря красивой окраске цветов и высоте, является одним из наиболее красивых тюльпанов. Изредка встречается среди тюльпанов Эстонской ССР. 


\section{Лилейные тюльпаны}

Тюльпаны данной группы характеризуются крупными лилейной формы цветами и отогнутыми наружу острыми концами листочков околоцветника. Одна из самых старых групп. Цветут они в Эстонской ССР почти одновременно с поздними Дарвиновскими тюльпанами. Обычно зацветают в конце мая - начале июня. Употребляются для срезки и оформления. Средняя высота растений 50-60 см.

\section{Picotée (Пикоте)}

Цветы среднего размера, лилейной формы, до 7 см длины. Цветок белый с узкой алой полоской по краям листочков околоцветника. С течением времени алая окраска распространяется до середины последних. Вершина листочков околоцветника острая, в средней их части имеются продольные бороздки кремового цвета. Основание листочков светло-желтое. Листочки внутреннего круга околоцветника отгибаются наружу. Тычиночные нити белые, короткие. Пыльники желтые, длиннее тычиночных нитей. Аромат незначительный. Растения 50-55 см высоты. Начало цветения $30 \mathrm{~V}-2 \mathrm{VI}$, а в холодный 1955 г. - $13 \mathrm{VI}$. Длительность цветения сорта в открытом грунте $11-25$ дней, а отдельных цветов при срезке - 7-10 дней. Хорошо размножается в условиях Эстонской ССР. Истинный коэффициент размножения 800-900\%. Сорта группы Picotée иногда встречаются среди тюльпанов Әстонской ССР. Благодаря изяществу своих цветов и интенсивному размножению, являются одними из лучших лилейных тюльпанов.

\section{Простые поздние тюльпаны}

В данную группу объединены сорта с более поздними сроками цветепия, в том числе старые английские Қоттэдж-тюльпаны. Сорта данной группы зацветают в Эстонской ССР позднее Простых ранних тюльпанов, сбычно в конце мая - начале июня. Тюльпаны большинства сортов с красивыми, крупными цветами, различной окраски и формы. Растения до $70-75$ см высоты, пригодны для срезки и оформления.

\section{Belle Jeanne (Прекрасная Жанна)}

Цветы среднего размера, длиной до 7 см, очень красивой яйцевидной формы, золотисто-желтого цвета. Вершина внешних листочков околоцветника округлая, а на внутренних незначительная выемка. На листочках околоцветника внтуреннего круга имеются продольные бороздки. Тычинки длиннее пестика. Тычиночные нити и пыльники желтые. При полном цветении цветок хорошо сохраняет красивую яйцевидную форму. Аромат нежный, приятный. Растения высокие, до 60 см высоты. Начало цветения $31 \mathrm{~V}-2 \mathrm{VI}$, а холодной весной 1955 г. - 13 VI. Длительность цветения сорта в открытом грунте $14-17$ дней, а при срезке - 9-10 дней. Истинный коэффициент размножения 1000-1070\%. Благодаря высоте стебля, красивым, яйцевидным, ярко окрашенным цветам и интенсивности размножения, является одним из наиболее красивых и эффектных тюльпанов. Сорт Belle Jeannе встречается среди тюльпанов Эстонской ССР. 


\section{Тюльпаны группы Триумф}

Данная группа выделена из Дарвиновской. Тюльпаны крупные, широкобокаловидной формы, цветы различной окраски. Растения обычно выше Дарвиновских, но в условиях Әстонской ССР средняя высота растений 52 -60 см, а у Дарвиновских 56-66 см. Высота некоторых тюльпанов группы Триумф доходит до $65 \mathrm{~cm}$, а Дарвиновских до 80 см. Таким образом, в условиях Әстонской ССР Дарвиновские сорта выше сортов группы Триумф.

Цветение сортов данной группы - конец мая-начало июня, т. е. почти одновременно с Дарвиновскими сортами. Употребляются для срезки, оформления и выгонки.

\section{Bandoeng (Бандунг)}

Цветы крупные, до 8 см длины, широкобокаловидной формы, темнокрасного цвета с коричневым оттенком в центре листочков околоцветника, Края последних имеют шарлаховый оттенок, а на внутренних рельефно выделяются желтая штриховка и продольные бороздки. Внутренние листочки околоцветника значительно длиннее наружных. Если смотреть сверху, то наружные листочки околоцветника представляют отчетливо очерченный треугольник. Вершина наружных листочков околоцветника несколько заостренная, а у внутренних - округлая. Основание звездчатое, желтое, которое на внутренних листочках околоцветника значительновыше, чем на наружных. В средней части желтого основания наблюдаются продолные бороздки оливкового цвета. С наружной стороны, у основания внутренних листочков околоцветника, коричнево-красный оттенок. Пыльники фиолетовые, почти одной длины с синими тычиночными нитями, беловатыми у основания. Высота растений 50-55 см. Начало цветения $29 \mathrm{~V}-2 \mathrm{VI}$, а в холодный 1955 г. - 6 VI. Продолжительность цветения сорта в открытом грунте 17-33 дня, при срезке - 8-9 дней. Истинный коэффициент размножения - $1100-1200 \%$. Сорт не встречается среди тюльпанов Эстонской ССР. Благодаря красивой окраске, форме и крупному размеру цветка, мощности развития и высоте стебля, является одним из красивейших тюльпанов группы Триумф.

\section{Kansas (Канзас)}

Цветы среднего размера, длиной до 6,5 см, бокаловидной формы. Цветок светло-кремового цвета с просвечивающими листочками околоцветника, которые незначительно отогнуты назад. На наружной стороне листочков околоцветника рельефно выражены белые продольные бороздки. Основание цветка светло-желтое. Тычиночные нити белые, средних размеров. Пыльники желтые. Аромат нежный, исключительно приятный. Высота растений 45-50 см. Начало цветения $31 \mathrm{~V}-2 \mathrm{VI}$, а холодной весной 1955 г. - 8 VI. При цветении очень хорошо сохраняется форма цветка. Длительность цветения сорта 13-28 дней, при срезке - 8-9 дней. Благодаря красивой окраске, форме и ароматичности, является одним из красивейших тюльпанов. Среди насаждений тюльпанов ЭССР встречается очень редко. Следует отметить, что белых тюльпанов в Эстонской ССР вообще очень мало.

\section{Бридеровы тюльпаны}

Сорта этой группы относятся к Староголландским тюльпанам, отличающимся быстротой размножения. В прежнее время Бридеровыми, или быстро размножающимися, назывались формы тюльпанов, из которых 
T $\mathbf{A} \mathbf{6}$ Л.

фенологических наблюдений, длительности цветения, разов и истинного коэффициента размножения лучших

в

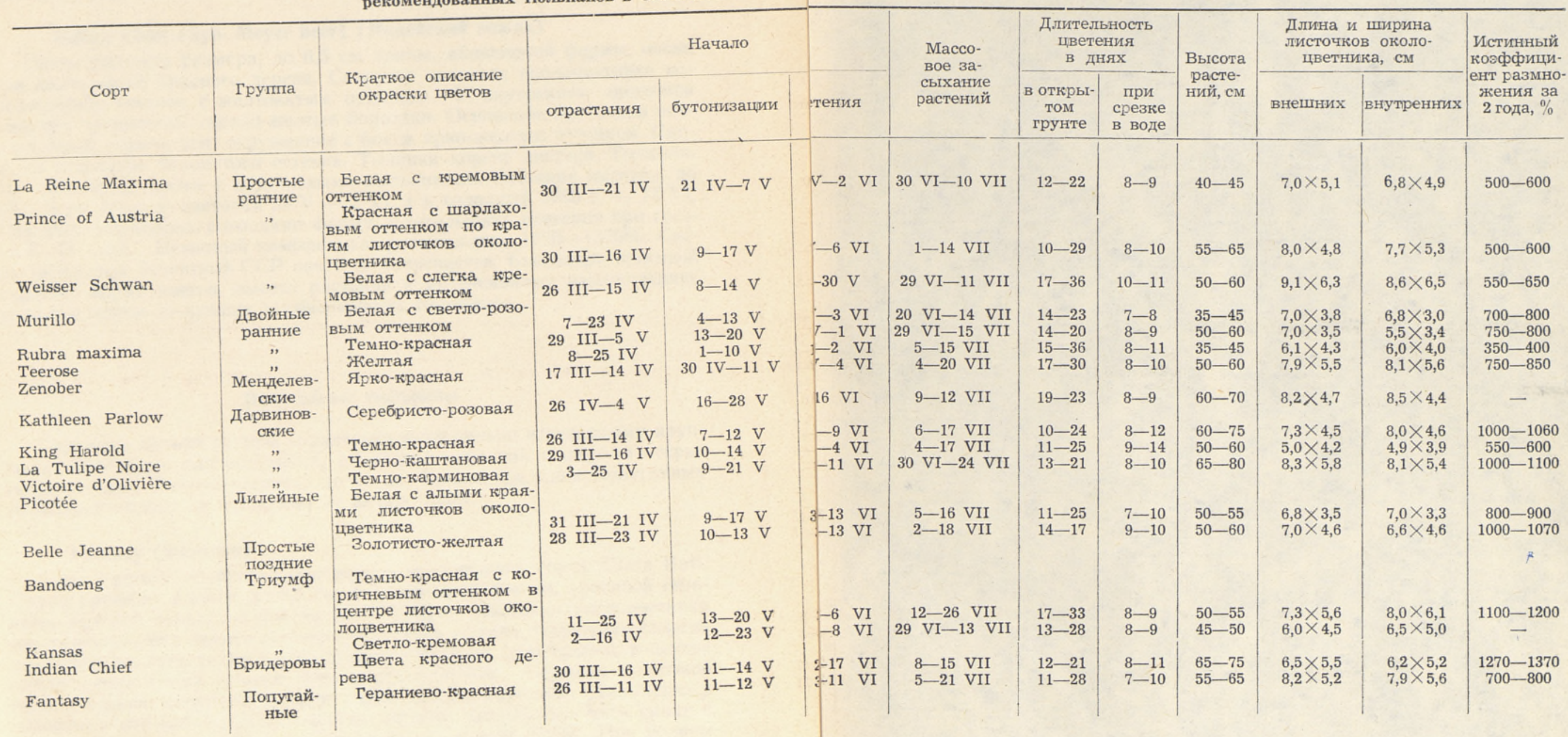


выделялись пестрые сорта. В настоящее время тюльпаны данной группы имеют тусклую окраску. Растения Бридеровых тюльпанов отличаются мощностью развития и достигают в условиях Эстонской ССР до $75 \mathrm{~cm}$ высоты. Цветы различной формы. Начало цветения в первых числах июня. Имеют склонность к пестрению, однако, в условиях Эстонской ССР этой склонности не наблюдалось. Бридеровы тюльпаны, благодаря своей красивой окраске, мощности развития и высоте стеблей, пригодны для срезки и оформления.

\section{Indian Chief (Syn. Meyer beer) (Индейский вождь)}

Цветы среднего размера, до 6,5 см длины, яйцевидной формы, очень красивого цвета красного дерева. Снаружи листочки околоцветника незначительно светлее, с желтоватым оттенком. У внутренних листочков имеются продольные светло-желтые бороздки. Основание листочков околоцветника коричневое, окруженное с боков ярко-желтым оттенком. Снаружи основание беловатого оттенка. Тычинки короче пестика. Тычиночные нити ярко-желтые с коричневыми пыльниками. Растения высокие, до 65-75 см. Начало цветения $29 \mathrm{~V}-3 \mathrm{VI}$, а в холодный 1955 г. - $17 \mathrm{VI}$. При цветении хорошо сохраняют форму. Длительность цветения при срезке 8-11 дней. Истинный коэффициент размножения $1270-1370 \%$. Среди тюльпанов Әстонской ССР почти не встречается. Благодаря красивой окраске, форме цветов, высоте растения и интенсивному размножению, является одним из лучших и красивейших тюльпанов.

\section{Попугайные тюльпаны}

Тюльпаны данной группы характеризуются сильно изрезанными крупными листочками околоцветника, различной окраской и широко открытыми цветами. Высота растений до 65 см. Начало цветения Попугайных тюльпанов падает на конец мая - началю июня.

\section{Fantasy' (Фантази)}

Copт Fantasy является спортивным отклонением сорта Clara Butt. Цветы крупные, длиной до 8,5 см, бокаловидной формы, красивой гераниево-красной окраски с красными полосками. Листочки околоцветника внутреннего круга яркого гераниево-красного оттенка. Наружная сторона листочков околоцветника светло-розовая с белыми прожилками, в центре наблюдаются также штрихи зеленоватого оттенка. Вершина листочков околоцветника округлая, а края очень сильно изрезаны. Дно белое, у основания дна наблюдаются голубые штрихи. Тычиночные нити синие с белым основанием. Пыльники темно-синие, короче нитей. При полном цветении относительно хорошо сохраняет форму цветка. Растения высокие, до 55-65 см. Начало цветения $31 \mathrm{~V}-2 \mathrm{VI}$, а в холодный 1955 г. 11 VI. Длительность цветения сорта 11-28 дней, при срезке - 7-10 дней. Истинный коэффициент размножения 700-800\%. Сорт является наиболее красивым среди группы Попугайных тюльпанов. Встречается среди насаждений тюльпанов Эстонской ССР.

Все вышеперечисленные сорта тюльпанов заслуживают внимания и распространения в Эстонской ССР. Кроме вышеописанных, имеется много красивых сортов тюльпанов, которые еще изучаются.

Ниже приводится список сортов тюльпанов, наиболее широко распространенных в настоящее время в Эстонской ССР, 
Простые ранние тюльпаны

Flamingo

Hermann Schlegel

Weber

Двойные ранние тюльпаны

Rubra maxima

Teerose

Wuurbaak

Менделевские тюльпаны

Prof. Zeeman

\section{Дарвиновские тюльпаны}

Bartigon

Gretchen (Syn. Margaret)

La Tulipe Noire

Pride of Haarlem

William Copland
Лилейные тюльпаны

Yellow Marvel

Picotée

Простые поздние тюльпаны

Belle Jeanne

Grenadier

Hanenokk (әстонское название сорта)

\section{Триумф}

Edith Eddy

President von Hindenburg

Попугайные тюльпаны

Fantasy

Среди насаждений тюльпанов в Эстонской ССР встречаются и другие сорта, но в очень ограниченном количестве.

Для наглядного представления приводим таблицу фенонаблюдений, длительности цветения, размеров и истинного коэффициента размножения лучших тюльпанов в Эстонской ССР, составленную на основании пятилетних наблюдений (1953-1957 гг.).

\section{Выводы}

В результате пятилетнего изучения проведены многолетние наблюдения над коллекцией сортовых тюлыпанов. Проведены фенонаблюдения, учет продолжительности цветения не только сортов в открытом грунте, но и цветов при срезке в воде. Осуществлены промеры и описание растений, а также учет интенсивности размножения тюльпанов в условиях Эстонской ССР. В итоге пятилетних работ выделен лучший сортимент тюльпанов в количестве 17 сортов, рекомендуемых для Эстонской ССР.

Автор считает своим долгом принести благодарность садоводу Института тов. Л. А. Салусте за помощь, оказанную ею в ходе настоящей работы.

Ннститут экспериментальной биологии Академии наук Эстонской ССР
Поступила в редакцию 23 I 1958 


\section{TULBID EESTI NSV-s}

V. Jesinovskaja,

póllumajandusteaduste kandidaat

\section{Resümee}

Käesoleval ajal ei rahulda Eesti NSV-s kasvatatavate tulpide sortiment elanikkonna nõudmisi, sest liiga kõrge protsendi moodustavad hilised, samuti lühikese õitsemisperioodiga ja meie tingimustes vähepaljunevad tulbisordid.

Praegu koosneb ENSV TA Eksperimentaalbioloogia Instituudi tulpidekollektsioon 210 sordist ja 30 metsikust liigist.

Tulbisibulad istutati välja septembris, vahemaaga $10 \times 20 \mathrm{~cm}$. Enne seda sai mulda väetatud, kusjuures kasutati 1 ha kohta 60 t sōnnikut või 80 t komposti, 4 ts kaalisoola, 1 t superfosfaati, 3 ts väävelhaput ammooniumi ja kahjurite tõrjeks 80 kg väävlit. Vegetatsiooniperioodil teostati 4 korda pealtväetamist koos vaheltharimise ja kobestamisega. Lahustamata väetisi anti 1 ha kohta järgmistes kogustes: 5 ts väävelhaput ammooniumi, 4 ts superfosfaati, 2 ts kaalisoola. Esimesel pealtväetamisel lisati hektari kohta $35 \mathrm{t}$ turbakomposti. Kolmas pealtväetamine toimus vedelväetisega, milleks lahjendati sõnnikuleotis veega (suhtes 1:4) ja lisandati vähesel hulgal mineraalväetisi. Väljakaevatud tulbisibulate suhte alusel väljakaevatud sibulapesade arvusse määrati sibulate paljunemiskoefitsient protsentides. Peale selle tunti huvi tulbisibulate arvu vastu igas väljakaevatud pesas.

Viieaastase uurimistöö resultaadina esitatakse tabel ja 17 parema Eesti NSV jaoks soovitatava tulbisordi kirjeldus, samuti Eesti NSV-s praegu kõige enam levinud sortide nimekiri.

Eesti NSV Teaduste Akadeemia

Eksperimentaalbioloogia Instituut
Saabus toimetusse

23. I I958

TULIPS IN THE ESTONIAN S. S. R.

\section{Yesinovskaya}

\section{Summary}

At present the garden varieties of tulips grown in the Estonian S. S. R, do not satisfy the demands of the people because the late varieties are dominating, and most of the well known varieties do not thrive well in our climate.

At present the collection of tulips of the Institute of Experimental Biology consists of 210 garden varieties and 30 wild species.

The bulbs were planted in September. Before the planting the soil had been manured (accounted on 1 ha - ab. - 2,5 acres) as follows: 60 tons of half-decayed farmyard manure, or 80 tons of compost, $400 \mathrm{~kg}$ ( 8 cwt.) murate of potash, 1 ton superphosphate, $300 \mathrm{~kg}$ (6 cwt.) sulphate of ammonia and against the pests $80 \mathrm{~kg}$ (17 lbs.) yellow sulphur. The distance between the bulbs was $10 \times 20 \mathrm{~cm}$ $(4 " \times 8 ")$.

During the vegetation period the tulips were 4 times top-dressed and after that hoed. Each time they were given artificial manures (per 1 ha): $500 \mathrm{~kg}$ (10 cwt.) sulphate of ammonia, $400 \mathrm{~kg}$ ( $8 \mathrm{cwt}$.) superphosphate and $200 \mathrm{~kg}$ (4 cwt.) murate of potash. At the first top-dressing 35 tons of peat-compost were added. For the third dressing liquid manure was used: a solution of farmyard manure mixed with water in the proportion of $1: 4$.

After the leaves of the tulips dried in summer, the bulbs were dug out and the actual percentage of propagation was accounted. Besides that the size of the bulbs in clumps was accounted.

The results of 5 year tests were given in form of tables and the best varieties were described.

Hereby are also listed some of the well-known varieties in the Estonian S. S. R.

Academy of Sciences of the Estonian S. S. R, Institute of Experimental Biology

Received Jan. 23, 1958 